\title{
Economic aspects of biodiesel use in agricultural production
}

\author{
Kirill Zhichkin ${ }^{1}$, Vladimir Nosov $^{2,3^{*}}$, Lyudmila Zhichkina ${ }^{1}$, Elena Kuznetsova $^{2}$, Yury \\ Abramov $^{2}$, and Larisa Poletaeva ${ }^{2}$ \\ ${ }^{1}$ Samara State Agrarian University, 2, Uchebnaya str., 446442, Kinel, Russia \\ ${ }^{2}$ K.G. Razumovsky Moscow State University of Technologies and Management, 73, Zemlyanoy val, \\ 109004, Moscow, Russia \\ ${ }^{3}$ Academy of the Investigative Committee of the Russian Federation, 12, Vrubel Str., 125080, Moscow, \\ Russia
}

\begin{abstract}
The article discusses the economic issues of biodiesel use in agricultural production. Study purpose: determination of the biodiesel production basic economic parameters for agricultural needs. Costs of biodiesel production, formation when using different crops, and costs of replacing traditional diesel fuel are calculated based on an example of a specific enterprise. To solve the problem posed in the study, used specialized software for calculating technological maps in crop production. As a result of the study, it was determined that the own production of biodiesel in the agricultural enterprise conditions is economically justified even at an oil prices low world level. Thanks to the implementation of the investment project to create biodiesel production, it is possible to reduce the cost of fuel and lubricants and thus increase production efficiency. Every year in the conditions of the economy from the use of biodiesel, an economic effect of 2358.7 thousand rubles can be reached.
\end{abstract}

\section{Introduction}

Currently, biodiesel worldwide production is expanding. Biodiesel is nothing more than methyl ether, which has the properties of a combustible material and is obtained as a result of a chemical reaction from vegetable fats $[1,2,3,4,5]$. Its chemical composition allows it to be used in diesel engines without other substances that stimulate ignition. The following useful properties of biodiesel should also be noted:

- biodiesel undergoes almost complete biological decay: in the soil or in water, microorganisms recycle $99 \%$ of biodiesel in 28 days;

- less $\mathrm{CO}_{2}$ emissions;

- low a number of components content in exhaust gases, such as carbon monoxide CO, unburned hydrocarbons, nitrogen oxides $\mathrm{NO}_{\mathrm{X}}$ and soot;

- low sulfur content;

- good lubricating characteristics. An increase in the service life of the engine and fuel pump by an average of $60 \%$ is achieved $[6,7,8,9,10]$.

\footnotetext{
*Corresponding author: novla@list.ru
} 
In addition, in the biofuels production the Russian Federation will have the opportunity to ensure the agricultural products sale, produce more than 7.5 million tons of biodiesel and increase agricultural productivity. This will improve the environment and the health of citizens, increase the agricultural producers income. Moreover, the import field for trading in greenhouse gas emissions under the Kyoto Protocol will expand. An additional plus is the lower cost compared to the diesel fuel purchase price.

\section{Methods and Materials}

To solve the problem posed in the study, used specialized software for calculating technological maps in crop production, developed by scientists of the Samara State Agrarian University, was used. With its help, the diesel fuel amount needed to complete the production program was determined. Subsequently, the monographic, abstract-logical method, situational and system analysis, economic-statistical methods, and the method of expert evaluations were used.

\section{Results and Discussion}

Biodiesel is a methyl ester. It is obtained from vegetable oils by transesterification: methanol is added to the vegetable oil in a ratio of approximately 9:1 and a small amount of catalyst. From one ton of vegetable oil and $111 \mathrm{~kg}$ of alcohol (in the presence of $12 \mathrm{~kg}$ of catalyst), approximately $970 \mathrm{~kg}(1100: 1)$ of biodiesel and $153 \mathrm{~kg}$ of primary glycerol are obtained. It is recommended to use potassium or sodium methoxides (methylates) as catalysts, after which the mixture is processed in a cavitation reactor $[11,12,13,14,15]$.

Biosam LLC in Samara developed 'MIXER' automated systems for the production of biodiesel with a capacity of 500 and 1000 liters per hour. The power consumption of cavitation reactors is 7.5 and $15 \mathrm{~kW}$, respectively. The operating mode is three-shift. The complexes are equipped with metering devices that allow feeding components into the reactor with high accuracy. The use of a hydrodynamic cavitation reactor allows one to reduce the reaction temperature to $30-35^{\circ} \mathrm{C}$ and to ensure that all components are fully involved in the transesterification reaction $[16,17,18]$.

After processing in a cavitation reactor, the mixture is fed to special separator columns, where it is divided into fractions. The complexes can work on absolutely any kind of vegetable oil, use methyl alcohol, potassium hydroxide, sodium hydroxide or acid as catalysts in the reaction.

A flexible dosing system allows to configure the installation not only on existing technologies for mixing the starting components, but also create the pecific technology that will most accurately take into account the local characteristics of the raw material $[19,20$, 21].

The calculation was carried out for a semiautomatic device with a 6 YL-80 press with a capacity of $600 \mathrm{~kg} /$ change of finished fuel. The biofuel thus obtained has passed the test in the Samara State Agrarian University and the Volga Technical Station, which showed that its characteristics correspond to the fuel developed in the traditional way.

The cost of $1 \mathrm{~kg}$ of biodiesel from rapeseed oil is 27.14 rubles. According to the Ministry of Agriculture of the Russian Federation information, the average price in Russia for summer diesel fuel as of August 1, 2018 amounted to 37.019 rubles/ton, which can be seen from Table 1 [22].

The next task was to determine the comparative effectiveness of the sunflower oil sale and the biodiesel production from own rapeseed oil. 
A comparative calculation is carried out on the basis of a conventional farm with an area of arable land of 1000 ha.

Table 1. Formation of the cost of biodiesel from rapeseed oil.

\begin{tabular}{|c|c|c|c|}
\hline № & Indicator & $\begin{array}{l}\text { Natural } \\
\text { indicator }\end{array}$ & $\begin{array}{c}\text { Cost } \\
\text { thousand } \\
\text { roubles. }\end{array}$ \\
\hline 1 & Rapeseed yield & $1.5 \mathrm{t} / \mathrm{ha}$ & \\
\hline 2 & $\begin{array}{l}\text { The cost of capital investments } \\
\text { (reconstruction of premises and } \\
\text { purchase of technological equipment) }\end{array}$ & & 2.569 .9 \\
\hline \multirow[t]{4}{*}{3} & Cost of components, total & $1 \mathrm{t}$ & 16.0 \\
\hline & including rapeseed oil & $885 \mathrm{~kg}$ & 14.2 \\
\hline & methanol & $100 \mathrm{~kg}$ & 1.0 \\
\hline & potassium hydroxide & $15 \mathrm{~kg}$ & 0.8 \\
\hline 4 & Depreciation & & 256.9 \\
\hline 5 & Salary & 2 men & 461.9 \\
\hline 6 & Electric power & $11088 \mathrm{KWh}$ & 54.6 \\
\hline 7 & Repair and maintenance costs & & 64.2 \\
\hline 8 & General running costs & & 1172.6 \\
\hline 9 & Total production costs per year & & 5863.0 \\
\hline 10 & The cost of rapeseed oil biodiesel & $1 \mathrm{t}$ & 27.14 \\
\hline \multicolumn{4}{|c|}{ For comparison (as of August 1,2018 ): } \\
\hline 11 & $\begin{array}{l}\text { The price of summer diesel fuel } \\
\text { average for Russia }\end{array}$ & $1 \mathrm{t}$ & 37.019 \\
\hline 12 & Gas station price & 10001 & more 35.0 \\
\hline
\end{tabular}

With an average diesel fuel demand of $60 \mathrm{~kg} / \mathrm{ha}$, arable land is necessary for the entire agricultural complex to carry out 60 tons of fuel per year [23].

The sunflower option is described as follows. In accordance with agricultural requirements, sunflower can be sown on the same area every eight years. This means that the maximum possible sowing area is 125 ha.

Sunflower yield is $1.0 \mathrm{t} / \mathrm{ha}$. In total, 125.0 tons of sunflower can be obtained. The oil yield from sunflower seeds is $45 \%$. In total, 56.25 tons of oil can be obtained.

Payment of transport services and processing - 93.75 thousand rubles.

At a selling price of 56.47 rubles $/ \mathrm{kg}$ (data from the Ministry of Agriculture of the Russian Federation as of $01 / 08 / 2018$ ), oil revenue is $3,176.4$ thousand rubles. With these funds, 85.8 tons of diesel fuel of the L-0.2-62 brand (summer) produced by the Novokuybyshevsky Oil Refinery (specific gravity $-0.86 \mathrm{~kg} / \mathrm{l}$ ) can be purchased.

To acquire 60 tons of diesel fuel, 87.4 hectares of sunflower must be sown. At a cost of $13,490.18 \mathrm{rubles} / \mathrm{ha}$, total costs will amount to $1,179.04$ thousand rubles.

The rapeseed option is described as follows. With a yield of $1.5 \mathrm{t} / \mathrm{ha}$ and an area of 125 ha, $187.5 \mathrm{t}$ of rapeseed can be obtained.

The oil yield is $42 \%$ or 78.75 tons. From this amount of oil, 87.81 tons of biofuel can be prepared. Based on the needs of the economy, 85.42 ha can be allocated for rapeseed.

The cost of 1 ha of rapeseed will amount to 10124.16 rubles. The cost of components is 136.5 thousand rubles. The cost of cultivation is 889.0 thousand rubles. Total total costs 1025.5 thousand rubles.

The direct economic effect of replacing sunflower with rapeseed is 153.54 thousand rubles/1000 ha.

Moreover, there is an indirect effect, expressed as follows:

- excess power churn can be used for squeezing oil for other purposes;

- improvement of soil fertility and phytosanitary situation; 
- obtaining an additional amount (29.3 tons) of high-protein feed for dairy cattle (rapeseed cake). Rapeseed cake has a higher feed value (protein content up to $40 \%$ versus $32-34 \%$ in sunflower). Currently, the sale price of oilcake is $11000-13000$ rubles. The farm may receive additional income in the amount of 322.3 thousand rubles [24].

In conclusion, the comparative efficiency of biodiesel and diesel fuel in a particular economy was calculated.

State policy aimed at supporting the interests of the fuel and energy complex. The farmers forced to seek new approaches to agricultural production. Among those tested and found their place the following can be named: the use of minimal and zero tillage, the use of energy-saving machines, etc. Currently, it appears necessaru to find a replacement for traditional fuel - the use of renewable energy sources, including vegetable oil based biodiesel.

To determine the biodiesel efficiency, using the program for calculating technological maps in crop production was used. As represented in Table 2, monthly diesel demand was determined [22].

Table 2. Amount of diesel fuel (biodiesel) required for field work, $t$.

\begin{tabular}{|l|c|c|c|c|c|c|c|c|}
\hline Crop & September & October & April & May & June & July & August & September \\
\hline $\begin{array}{l}\text { Winter } \\
\text { wheat }\end{array}$ & 0.0 & 13.4 & 4.1 & 4.4 & 0.5 & 11.4 & 5.1 & 0.0 \\
\hline $\begin{array}{l}\text { Spring } \\
\text { wheat }\end{array}$ & 0.0 & 2.5 & 3.1 & 0.0 & 0.4 & 0.0 & 3.3 & 0.0 \\
\hline Barley & 0.0 & 4.3 & 5.3 & 0.0 & 0.7 & 0.0 & 5.7 & 0.0 \\
\hline Oats & 0.0 & 2.4 & 3.0 & 0.0 & 0.4 & 0.0 & 2.3 & 0.0 \\
\hline Sunflower & 1.8 & 10.6 & 1.8 & 2.4 & 1.5 & 0.4 & 0.0 & 2.3 \\
\hline $\begin{array}{l}\text { Perennial } \\
\text { grasses }\end{array}$ & 0.0 & 0.0 & 0.8 & 0.0 & 14.7 & 0.0 & 0.0 & 0.0 \\
\hline $\begin{array}{l}\text { Annual } \\
\text { grasses }\end{array}$ & 7.0 & 0.0 & 5.7 & 0.0 & 0.0 & 16.9 & 0.0 & 0.0 \\
\hline $\begin{array}{l}\text { Silage } \\
\text { Corn }\end{array}$ & 15.6 & 0,0 & 1.9 & 9.1 & 2.2 & 1.7 & 0.0 & 50.3 \\
\hline Rape & 3.0 & 8.6 & 2.2 & 3.1 & 0.5 & 0.0 & 2.7 & 0.0 \\
\hline TOTAL & 27.4 & 41.8 & 27.9 & 19.0 & 20.8 & 30.3 & 19.0 & 52.6 \\
\hline
\end{tabular}

The greatest demand falls on the month of September, when plowing is carried out, which is the most energy-intensive operation in traditional crop cultivation technology. To determine comparative efficiency, it is proposed to use the sowing structure of 2018 , since at the moment it is this structure that most accurately reflects the financial and organizational capabilities of the enterprise in the field work [24]. It is proposed to add to this structure the necessary area for the cultivation of rapeseed (400 ha), which is sufficient to provide biodiesel for the economy. As a result, the sown area is 3952 ha, according to Table 3.

Table 3. Proposed structure sowing acreage.

\begin{tabular}{|c|c|}
\hline Crop & Sowing area, ha \\
\hline Winter wheat & 470 \\
\hline Spring wheat & 333 \\
\hline Barley & 573 \\
\hline Oats & 320 \\
\hline Sunflower & 308 \\
\hline Perennial grasses & 474 \\
\hline Annual grasses & 620 \\
\hline Silage Corn & 454 \\
\hline
\end{tabular}




\begin{tabular}{|c|c|}
\hline Rape & 400 \\
\hline TOTAL & 3952 \\
\hline
\end{tabular}

Based on the per hectare diesel fuel demand for the cultivation of these crops, as well as the size of the sown area, the cost of diesel fuel for the current year can be determined. The total demand for diesel fuel is 238.8 tons.

To determine the cost of diesel fuel, the amount found must be multiplied by the purchase price of fuel and lubricants (37.019 rubles / kg).

Table 4. Costs of biodiesel for the entire sown area of the enterprise, thousand rubles.

\begin{tabular}{|l|c|c|c|c|c|c|c|c|}
\hline \multicolumn{1}{|c|}{ Crop } & September & October & April & May & June & July & August & September \\
\hline $\begin{array}{l}\text { Winter } \\
\text { wheat }\end{array}$ & 0.0 & 364.4 & 111.6 & 118.5 & 14.8 & 308.6 & 139.2 & 0.0 \\
\hline $\begin{array}{l}\text { Spring } \\
\text { wheat }\end{array}$ & 0.0 & 68.1 & 83.5 & 0.0 & 10.5 & 0.0 & 89.3 & 0.0 \\
\hline Barley & 0.0 & 117.1 & 143.7 & 0.0 & 18.0 & 0.0 & 153.6 & 0.0 \\
\hline Oats & 0.0 & 65.4 & 80.2 & 0.0 & 10.1 & 0.0 & 61.5 & 0.0 \\
\hline Sunflower & 50.2 & 286.6 & 49.4 & 64.8 & 40.1 & 9.7 & 0.0 & 63.4 \\
\hline $\begin{array}{l}\text { Perennial } \\
\text { grasses }\end{array}$ & 0.0 & 0.0 & 21.5 & 0.0 & 399.4 & 0.0 & 0.0 & 0.0 \\
\hline $\begin{array}{l}\text { Annual } \\
\text { grasses }\end{array}$ & 190.0 & 0.0 & 155.5 & 0.0 & 0.0 & 458.7 & 0.0 & 0.0 \\
\hline $\begin{array}{l}\text { Silage } \\
\text { Corn }\end{array}$ & 422.5 & 0.0 & 52.9 & 246.2 & 59.1 & 44.9 & 0.0 & 1364.0 \\
\hline Rape & 81.4 & 232.6 & 59.4 & 85.0 & 12.6 & 0.0 & 72.0 & 0.0 \\
\hline TOTAL & 744.1 & 1134.3 & 757.7 & 514.5 & 564.7 & 821.8 & 515.6 & 1427.4 \\
\hline
\end{tabular}

For field work, it is necessary to purchase diesel fuel for 8838.7 thousand rubles.

The cost of $1 \mathrm{~kg}$ of rapeseed oil-based biodiesel is 27.14 rubles. The costs of producing the required amount of biodiesel are presented in Table 4 . The amount of expenses, taking into account the annual production program, amounted to 6480.0 thousand rubles.

The economic effect is 2358.7 thousand rubles. The payback of this event is 1.36 .

\section{Conclusion}

In the course of the work, a business plan was developed for an investment project to create a mini-biodiesel production workshop. The required investment amount is 2570 thousand rubles, which consist of the acquisition of equipment and the reconstruction of a grain warehouse in the farm. Over the five years of the project, a net discounted income of 2.8 million rubles would be obtained, the payback period is 25 months at a discount rate of $11 \%$.

As a result of the study, it was determined that the own production of biodiesel in the agricultural enterprise conditions is economically justified even at an oil prices low world level. Thanks to the implementation of the investment project to create biodiesel production, it is possible to reduce the cost of fuel and lubricants and thus increase production efficiency. Every year in the conditions of the economy from the use of biodiesel, an economic effect of 2358.7 thousand rubles can be reached.

\section{References}

1. E. Yanzina, V. Yanzin, O. Mamai, V. Parsova, Eng. Rur. Dev. Conf. Proc., 177-122 (2019) doi: 10.22616/ERDev2019.18.N134 
2. M. Canakci, H. Sanli, J. Ind. Microbiol. Biot. 35, 431-441 (2008) doi: 10.1007/s10295008-0337-6

3. Demirbas, Energy Convers. Manag. 50, 14-34 (2009) doi: 10.1016/j.enconman.2008.09.001

4. S. Karmakar, S. Mukherjee, Bioresour. Technol. 101, 7201-7210 (2010) doi: 10.1016/j.biortech.2010.04.079

5. M. Mofijur, H. Masjuki, M. Kalam, A. Atabani, M. Shahabuddin, S. Palash, M. Hazrat, Renew. Sust. Energ. Rev. 28, 441-455 (2013) doi: 10.1016/j.rser.2013.07.051

6. V. Nosov, M. Tindova, K. Zhichkin, M. Mirgorodskaya, IOP Conf. Ser.: Earth Environ. 337, 012014 (2019) doi:10.1088/1755-1315/337/1/012014

7. L. Chuah, J. Klemeš, S. Yusup, A. Bokhari, M. Akbar, J. Clean. Prod. 146, 181-193 (2017) doi: 10.1016/j.jclepro.2016.05.017

8. S. Hoekman, A. Broch, C. Robbins, E. Ceniceros, M. Natarajan, Renew. Sust. Energ. Rev. 16, 143-169 (2012) doi: 10.1016/j.rser.2011.07.143

9. T. Issariyakul, A. Dalai, Renew. Sust. Energ. Rev. 31, 446-471 (2014) doi: 10.1016/j.rser.2013.11.001

10. G. Knothe, L. Razon, Prog. Energ. Combust. Sci. 58, 36-59 (2017) doi: 10.1016/j.pecs.2016.08.001

11. M. Borges, L. Díaz, Renew. Sust. Energ. Rev. 16, 2839-2849 (2012) doi: 10.1016/j.rser.2012.01.071

12. A. Lee, K. Wilson, Catal. Today 242, 3-18 (2015) doi: 10.1016/j.cattod.2014.03.072

13. R. Shan, L. Lu, Y. Shi, H. Yuan, J. Shi, Energy Convers. Manag. 178, 277-289 (2018) doi: 10.1016/j.enconman.2018.10.032

14. F. Ullah, L. Dong, A. Bano, Q. Peng, J. Huang, J. Energy Inst. 89, 282-292 (2016) doi: 10.1016/j.joei.2015.01.018

15. G. Baskar, R. Aiswarya, Renew. Sust. Energ. Rev. 57, 496-504 (2016) doi: 10.1016/j.rser.2015.12.101

16. A. Abbaszaadeh, B. Ghobadian, M. Omidkhah, G. Najafi, Energy Convers. Manag. 63, 138-148 (2012) doi: 10.1016/j.enconman.2012.02.027

17. I. Ambat, V. Srivastava, M. Sillanpää, Renew. Sust. Energ. Rev. 90, 356-369 (2018) doi: 10.1016/j.rser.2018.03.069

18. E. Aransiola, T. Ojumu, O. Oyekola, T. Madzimbamuto, D. Ikhu-Omoregbe, Biomass Bioenergy 61, 276-297 (2014) doi: 10.1016/j.biombioe.2013.11.014

19. I. Atadashi, M. Aroua, A. Abdul Aziz, N. Sulaiman, Renew. Sust. Energ. Rev. 16, 3275-3285 (2012) doi: 10.1016/j.rser.2012.02.063

20. H. Fukuda, A. Kondo, H. Noda, J. Biosci. Bioeng. 92, 405-416 (2001) doi: 10.1016/S1389-1723(01)80288-7

21. C. Lin, H. Lin, L. Hung, Fuel 85, $1743-1749$ (2006) doi: 10.1016/j.fuel.2006.03.010

22. K. Zhichkin, V. Nosov, L. Zhichkina, Zh. Dibrova, T. Cherepova, IOP Conf. Ser.: Earth Environ. 315, 022023 (2019) doi:10.1088/1755-1315/315/2/022023

23. O. Mamai, I. Mamai, M. Kitaeva, Conf. Proc. Dig. Age: Chances, Chal. Fut. 84, 359365 (2020) doi:10.1007/978-3-030-27015-5_43

24. K. Zhichkin, V. Nosov, L. Zhichkina, IOP Conf. Ser.: Earth Environ. 403, 012073 (2019) doi:10.1088/1755-1315/403/1/012073 